\title{
Influence of the Chernaya River Runoff during High and Low Water on the Ecological State of the Apex of the Sevastopol Bay Water Area
}

\author{
E. E. Sovga, T. V. Khmara* \\ Marine Hydrophysical Institute of RAS, Sevastopol, Russian Federation \\ *xmara@mhi-ras.ru
}

Purpose. Climatic conditions for the winter and spring river floods in Crimea are assessed by the example of the Chernaya River. The scientific literature data permitted to analyze salinity dynamics in the Sevastopol Bay during an intensive flood, which is extremely rare in contrast to the high water cases occurring rather frequently.

Methods and Results. Based on the available information and using the analyzed in situ data on the Sevastopol Bay apex and the Chernaya River obtained by the Marine Hydrophysical Institute in 2007-2017, considered are the meteorological conditions for a winter-spring high water. The impact of high water upon the hydrological regime and the ecological state of the Sevastopol Bay apex and the Chernaya River mouth is analyzed. Contribution of a winter-spring high water to pollution of the Sevastopol Bay apex with nutrients is assessed. The ecological state of the bay apex during the peculiar winter-spring high water in February, 2015 is compared to that during the low water in September, 2015.

Conclusions. The increased content of inorganic nitrogen during a winter-spring flood should be taken into account while calculating the assimilation capacity of the ecosystem under study and assessing the trophic index. The joint analysis of the expeditionary in situ data and the available information from the scientific literary made it possible to conclude that in course of the last decade, salinity in the Chernaya River mouth gradually increased. This can testify the fact that frequency and intensity of the winter-spring floods tend to go down.

Keywords: apex of the Sevastopol Bay, Chernaya River, winter-spring flood, nutrients, trophic level.

Acknowledgments: the investigation is carried out within the framework of the state task on theme No. 0827-2018-0004 "Complex interdisciplinary investigations of the oceanologic processes conditioning functioning and evolution of the Black and Azov seas' ecosystems of the coastal zones" and at the RFBR partial support of the research project No. 18-45-920002 "Self-purification capacity of ecosystems of the Sevastopol Bay water areas depending on the anthropogenic load".

For citation: Sovga, E.E. and Khmara, T.V., 2020. Influence of the Chernaya River Runoff during High and Low Water on the Ecological State of the Apex of the Sevastopol Bay Water Area. Physical Oceanography, [e-journal] 27(1), pp. 28-36. doi:10.22449/1573-160X-2020-1-28-36

DOI: $10.22449 / 1573-160 \mathrm{X}-2020-1-28-36$

(C) E.E. Sovga, T.V. Khmara, 2020

(C) Physical Oceanography, 2020

\section{Introduction}

In the hydrological sense, a high water period is a sharp and short-term rise in water in a river resulting from heavy rains, as well as rapid melting of snow during winter thaws. Unlike a seasonal flood, high water occurs at any time of the year and is not repeated periodically [1]. In Crimean rivers the high waters occur mainly in the winter-spring period from December - November to April, which is associated with the passage of Mediterranean cyclones. For the same reason, the winter in Crimea is relatively wet, with periodic rainfall and low evaporation. 
Frequent thaws in winter are due to large air temperature fluctuations and lead to instability of the snow cover. At active snowmelt with heavy precipitations, catastrophic high water can form [2]. The most high water-hazardous river of Sevastopol is the Chernaya River.

The Chernaya River is one of the most significant rivers in the Sevastopol region in terms of length and water content (average monthly river discharge is $1.82 \mathrm{~m}^{3} / \mathrm{s}$, the maximum one is $15.2 \mathrm{~m}^{3} / \mathrm{s}$ ) [3]. It belongs to the group of rivers in the northwestern slope of the Main Ridge of the Crimean Mountains. Winter-spring high waters on the river are observed from the late November to March, less often in April. According to [4], the most catastrophic high water in the Chernaya River Basin took place in December 1939.

During the high water the water level in the river can rise by 2-3 $\mathrm{m}$ and can be comparable with the volume of water in the bay itself [5]. Even in low water periods, river discharge during extreme floods can increase by an order of magnitude or more. Thus, the Chernaya River runoff has a significant impact on the ecological state of the Sevastopol Bay water area.

The Sevastopol Bay is the estuary near-shore zone of the Chernaya River an enclosed estuary-type water area with limited water exchange, which is under technogenic (shipping, moorage, hydrotechnical works) and anthropogenic (domestic sewage and storm runoff) load. The waters of Chernaya River, which flows into the apex of the Sevastopol Bay near Inkerman, carry an additional amount of nutrients and other pollutants. Water pollution occurs as a result of the wastewater discharge (insufficiently treated with their increasing volume) and emergency discharges $[6,7]$.

In [8], the trends in the temperature and salinity of the Chernaya River estuarine zone and the Sevastopol Bay apex are considered to assess the dynamics of species diversity and quantitative indicators of ichthyofauna for 2006-2014. It was noted that, according to the data for 2009-2014, the observed trend towards an increase in salinity continued, while an increase in salinity was observed both at the surface and at the bottom. Sometimes the difference between the indicators of 2006 and 2014 was about 10 \%. In general, from June 2006 to December 2014 the dynamics of estuary zone displacement upstream the Chernaya River was observed.

In [9], based on the expeditionary data on the Sevastopol Bay and the Chernaya River obtained from 2007 to 2017, the content of the main biogenic cycle elements is analyzed, the contribution of the Chernaya River waters to the total budget of dissolved inorganic carbon and components of the carbonate system is studied. The length and temporal variability of the Chernaya River Sevastopol Bay geochemical barrier zone are determined.

Interannual variation of the nutrient concentration in the Sevastopol Bay waters for 2006-2010 is given in [10]. The content of nutrients in the bay is directly dependent on the sources of their input (domestic, river and storm runoffs, etc.) and is characterized by the maximum concentrations of mineral forms of nitrogen, silicon and phosphates in the Yuzhnaya Bay and Oil Port, which are exposed to the greatest anthropogenic impact. It is concluded that anthropogenic factors have a greater effect on the nutrient content in the bay than natural biochemical processes. 
In order to assess the sources of pollutant inflow into the Chernaya River waters, the paper [11] presents the results of spatial distribution analysis of oxygen and elements of the main biogenic cycle in the Chernaya River waters from Chernorechenskoe Reservoir to the Inkerman Bay. Based on the data of long-term hydrochemical monitoring, it was revealed that the Chernorechenskoe Reservoir waters are a source of nitrates, and in some years - silicon. Other nutrients, in particular phosphates and ammonium, get into the river and bays from household sewage in the lower course of the river, as well as from sewage discharges of settlements and enterprises located in the water protection zone.

The distribution of phosphorus and silicon mineral forms in the mixing zone of the Chernaya River and Sevastopol Bay waters during the winter (January 31 February 2, 2004) is presented in [12], where it is shown that in the Sevastopol Bay the quality of the surface layer water in the apex worsens as we move closer to the Chernaya River mouth.

In [13], the impact of stormwater runoff in February 2015 on the extreme values of hydrochemical parameters in the surface waters of the Inkerman Bay in comparison with the Yuzhnaya Bay apex was estimated. An increase in the content of silicic acid in the Sevastopol Bay mouth as well as in the Yuzhnaya Bay apex during showers and a significant increase in the content of nitrates in the bay mouth are shown.

In all of the mentioned papers, special attention was not paid to the impact of specific floods and low water on the ecological state of the Sevastopol Bay in general and its apex in particular. In contrast to these publications, the dynamics of variation of the Sevastopol Bay salinity in winter is calculated in [14] using numerical modeling. The authors analyzed the processes related to the penetration of the Chernaya River fresh water into the bay and the influx of salt water from the open sea. It is noted that the model cannot correctly describe the real situation in the bay, since it was during the considered time period that no direct observations were made at the sea.

The purpose of this work was to assess the effect of flood regime and low water on the variation of the hydrological parameters of the Sevastopol Bay apex; to determine the hydrometeorological conditions that contribute to the occurrence of floods, the expansion or reduction of the boundaries of this effect over the bay; to determine the water pollution levels of the studied water area by nutrients in the flood and low-water periods and to analyze the general ecological state of the studied water area.

\section{Research materials}

In order to assess the impact of river runoff on the Sevastopol Bay ecological state, the data of chemical parameters (the content of nutrients, mineralization) in the apex of the Sevastopol Bay and the Chernaya River estuary are considered. We analyzed an array of expeditionary data on the hydrological and hydrochemical regimes of Sevastopol Bay apex water area, which is affected by the Chernaya River runoff, for 2007-2017, from the Oceanographic Data Bank of Marine Hydrophysical Institute (ODB MHI). In addition to the indicated array, we also analyzed available published information on meteorological conditions that caused the occurrence of the flood regime of the Chernaya River and its duration. 
The presented ODB MHI database on hydrology and hydrochemistry for 2007-2017 by seasons amounted to: 90 stations for the bay and the river in winter, 70 stations in summer, 40 stations in autumn and 30 in spring. At all stations in the bay water area (on the surface and at the bottom) and in the surface layer of the Chernaya River water the following hydrochemical parameters were analyzed: dissolved oxygen $\left(\mathrm{O}_{2}\right)$, phosphates $\left(\mathrm{PO}_{4}{ }^{3-}\right), \mathrm{P}_{\text {tot }}$, silicon $\left(\mathrm{SiO}_{3}{ }^{2-}\right)$, nitrites $\left(\mathrm{NO}_{2}{ }^{-}\right)$, nitrates $\left(\mathrm{NO}_{3}{ }^{+}\right)$, ammonium $\left(\mathrm{NH}_{4}{ }^{+}\right)$.

\section{Results and discussions}

As a result of this database analysis, a winter flood in February 2015 was identified. The variations in hydrological and hydrochemical parameters during the flood period, the level of flood distribution in the Sevastopol Bay and the meteorological situation that accompanied its occurrence are assessed. The summer-autumn period, when the conditions for the occurrence of low water prevail most often, is analyzed. An assessment of variation in hydrological and hydrochemical parameters during the low-water period in the Sevastopol Bay apex and in the Chernaya River estuary area is given.

The Sevastopol Bay apex - the object of the study of this work - is shallow: its average depth is $4.7 \mathrm{~m}$ and the maximum is $10.8 \mathrm{~m}$. It includes the Chernaya River mouth (3.5 $\mathrm{m}$ depth), a navigation canal (9 $\mathrm{m}$ depth), to the right of which the Inkerman Bay of $7.5 \mathrm{~m}$ depth is located, and the Oil Port, separated from the bay itself by a long breakwater. Station schemes in the apex of the bay and at the Chernaya River mouth are given in Fig. 1.
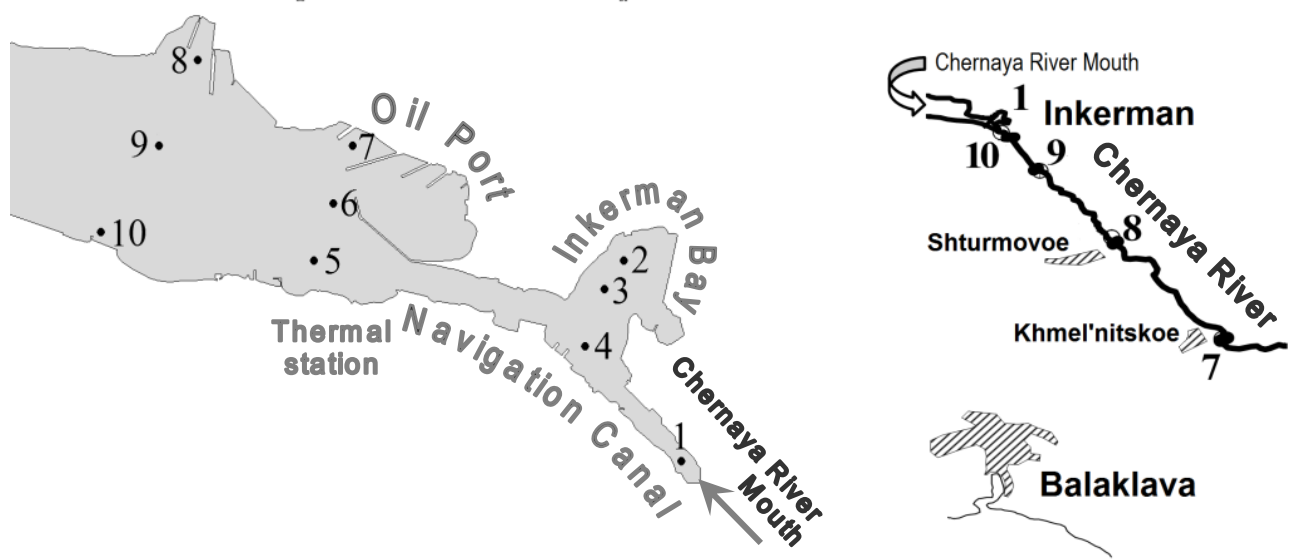

F i g. 1. Scheme of the sample stations in the Sevastopol Bay apex and in the Chernaya River

Data on distribution of temperature, salinity and dissolved oxygen in the bay apex during the winter flood (February 4, 2015) are presented in Fig. 2. Data analysis revealed the fact that during the flood period desalinated (salinity fluctuation limits of 4.0-16.5\%), oxygen-enriched (from 7.68 to $7.2 \mathrm{ml} / \mathrm{l}$ ) waters distribute beyond the Oil Port at a slight fluctuation in water temperature (from 7.6 to $8.9^{\circ} \mathrm{C}$ ). 

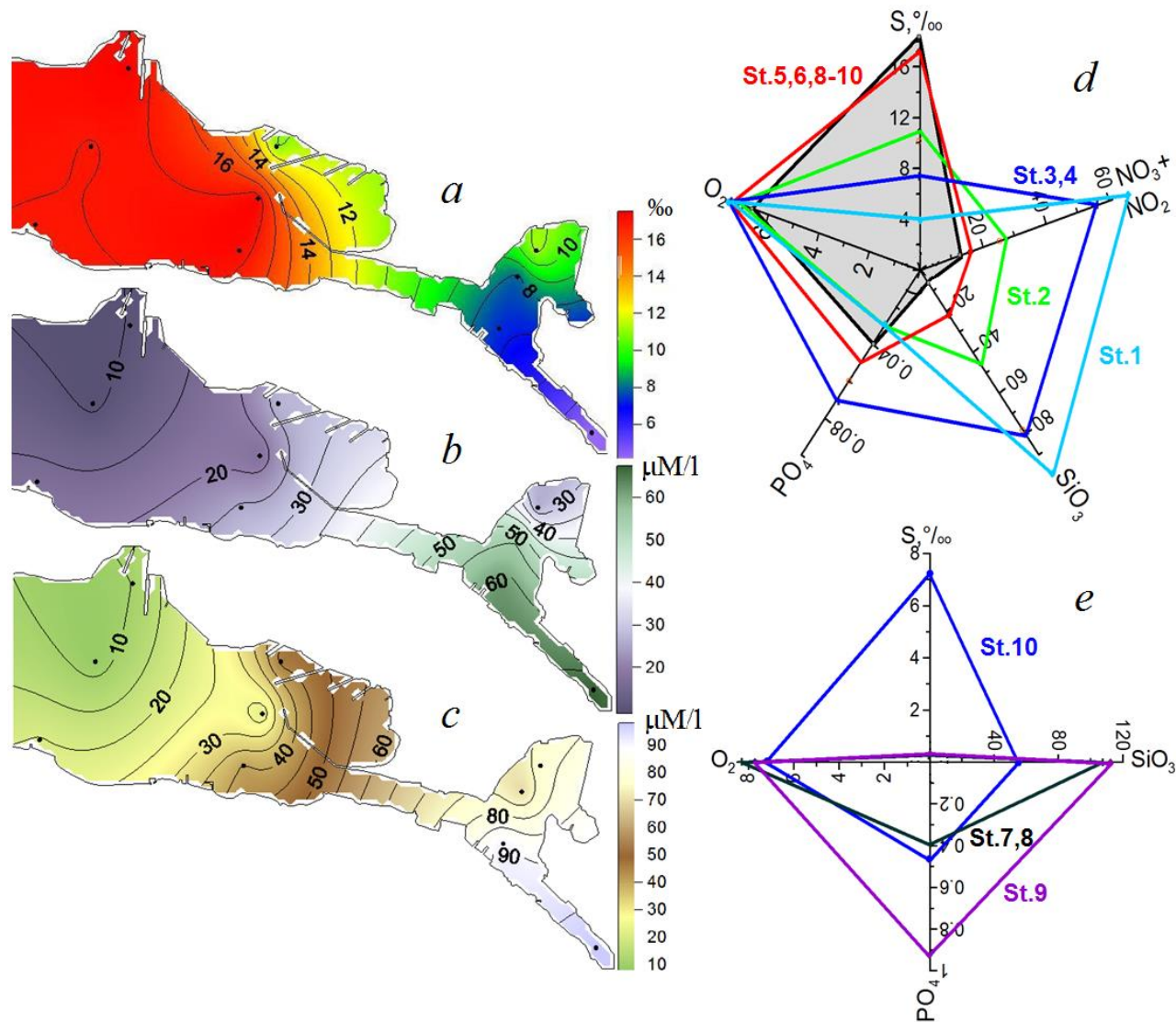

F i g. 2. Distribution of salinity $(a)$, nitrates $(b)$ and silicon $(c)$ in the surface waters; diagrams of the hydrological and hydrochemical indices in the eastern part of the Sevastopol Bay $(d)$ and in the Chernaya River (e) during the flood on February 4, 2015

On the estuary surface almost fresh (4.4-7.24 \%) river water distributes to the Oil Port, completely occupied by brackish waters with the salinity above $12 \%$. In the Inkerman Bay region, the upper water layer is desalinated water $(11.26 \%$ ) with $7.4{ }^{\circ} \mathrm{C}$ temperature and estuarine waters are underlain by salty sea water $(17.9 \%$ ). In the region of Thermal Station, salinity gradually rises and reaches about $17 \%$ at a distance of about $1000 \mathrm{~m}$ from the river mouth.

Flood waters can affect not only salinity and oxygen content, but also the pollution level of bay waters with nutrients. During the flood in the Chernaya River lower course the content of dissolved oxygen in the surface layer was stable and equal to about $7.5 \mathrm{ml} / \mathrm{l}$, the concentration of nutrients was high: silicates 98 $91.6 \mu \mathrm{M} / \mathrm{l}$, phosphates $0.03-0.08 \mu \mathrm{M} / \mathrm{l}$, nitrates - up to $67.3 \mu \mathrm{M} / \mathrm{l}$, nitrites - up to $0.25 \mu \mathrm{M} / \mathrm{l}$ [15]. The oxygen indices did not change much with depth, despite a noticeable increase in salinity, but at the same time, the concentrations of silicon, phosphates, and nitrates decreased (Fig. 2). 
In the Oil Port the oxygen content in the surface layer remained at $7-7.3 \mathrm{ml} / \mathrm{l}$ level, the concentration of silicates dropped to $40-10 \mu \mathrm{M} / 1$, the one of nitrates - to $25.8-10.2 \mu \mathrm{M} / 1$.

From Fig. 2 it follows that the desalinated surface water of the flood distributes all the way to the Oil Port and is enriched in silicon and nitrates; the ammonium content in them is slightly increased. The waters in the Chernaya River estuary (Fig. 2) are also enriched with silicon and phosphates; unfortunately, there are no data on nitrates in river water.

The discovered winter flood in February 2015 made it possible to assess the level of the bay contamination with nutrients (silicon and nitrates). The causes of flood that took place in February are related to the meteorological situation in this period. According to the site https://rp5.ru/, at the beginning of February 2015 rather high air temperature was noted in the Sevastopol region, which could contribute to the melting of snow in the mountains. In addition, rain showers were observed on the eve of the survey (Fig. 3).

An analysis of the results of ODB MHI field observations for 2007-2017, carried out in the Sevastopol Bay apex and in the Chernaya River estuary, showed that in the autumn-winter period the levels of pollution with nutrients (phosphates, nitrites and nitrates, silicon) of the considered water area and the Yuzhnaya Bay the most environmentally problematic part of the Sevastopol Bay - are comparable.

The data of the long-term (1998-

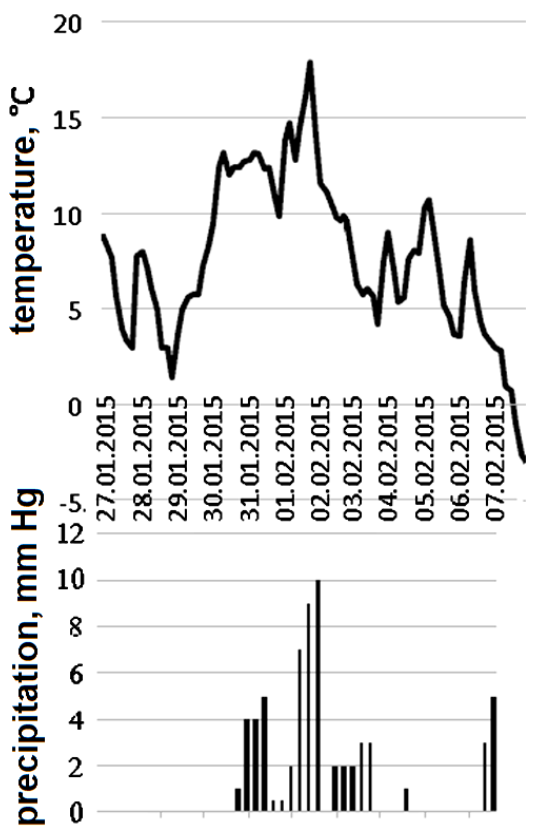

F i g. 3. Air temperature and precipitation amount at late January-early February, 2015 2011) Sevastopol Bay and its apex monitoring in the winter and autumn periods $[10,11]$, as well as assessments of the trophicity level and self-purification ability of the ecosystem of separated bay water areas [16-19] showed that the maximum trophicity index of each region occurs in the autumn-winter period, when the concentrations of nutrients, especially mineral forms of nitrogen, are high and are the main factor determining the eutrophication level of the Sevastopol Bay waters. High concentrations of phosphates, and especially mineral forms of nitrogen, make the largest relative contribution to the calculated index formula. One of the causes for the increase in the content of nutrients in the bay apex may be the effect of winter and autumn floods, as shown by our data on winter flood in February 2015 (Fig. 2). It is obvious that the increased inorganic nitrogen content during the winter floods

should be taken into account when assessing the assimilative capacity of the Sevastopol Bay apex waters because it can result in the decrease of selfpurification ability of its ecosystem [19]. 
Now we are to consider the situation with the variation of hydrochemical parameters in the bay apex during the summer low-water period (September 2015).

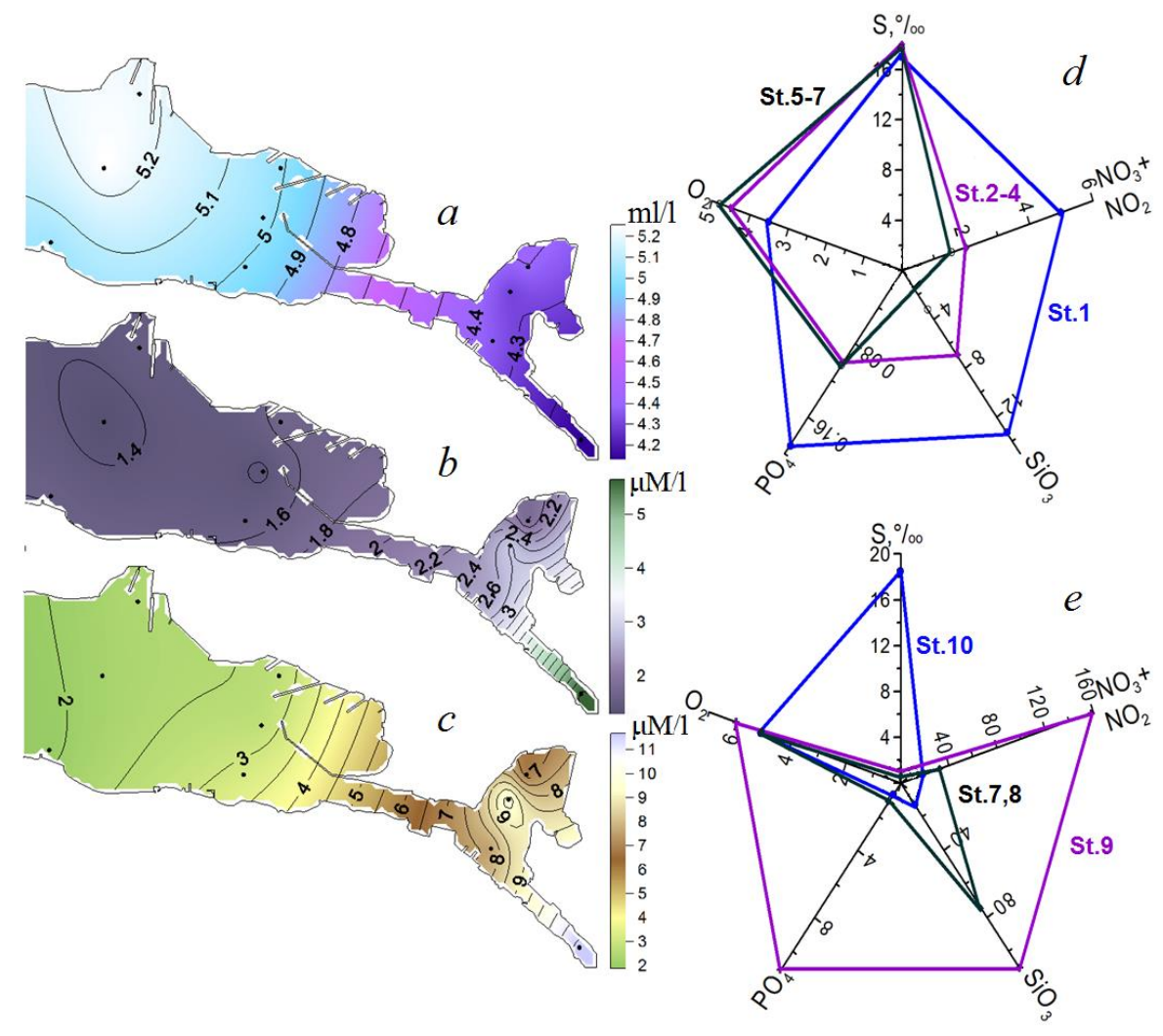

F i g. 4. Distribution of oxygen $(a)$, nitrates $(b)$ and silicon $(c)$ in the surface waters; diagrams of the hydrological and hydrochemical indices in the eastern part of the Sevastopol Bay $(d)$ and in the Chernaya River $(e)$ during low water on September 8, 2015

During the low water period on September 8, 2015, the salinity in both the surface and in the bottom water layer was uniform throughout the apex (17.6$17.9 \%$ ), except for the river mouth, where $16.9 \%$ value was recorded. However, a week later, on September 15, the salinity was already $18.4 \%$ at the river mouth.

The distribution of nutrients in the bay apex during the low water period is quite uniform throughout the water area of the bay apex, except for the river mouth where very slightly increased concentrations of silicic acid, nitrates and ammonium were observed (Fig. 4).

It should be pointed out that, in contrast to the flood regime, when a significant part of the bay apex water area is covered with desalinated waters, during the lowwater periods with a slight increase in nitrates these waters do not even enter the water area of the Inkerman Bay, while the waters with increased silicon content, on the contrary, are observed on approach to the Oil Port.

During the low-water period, the increased concentrations of silicon and nitrates were noted at the stations located upstream of the Chernaya River near 
the settlements. The maximum was recorded at station 9, which, apparently, is related to the untreated household sewage entering the river.

\section{Conclusion}

The Sevastopol Bay apex, as the most environmentally vulnerable area, is under the significant effect of winter-spring floods on the Chernaya River. The desalinated flood waters (February 2015) affected the level of nutrient entry into the bay, increasing the content of inorganic forms of nitrogen and silicates.

The increased values of nutrient content during the winter-spring flood regime must be taken into account when calculating the assimilation capacity of the studied water area ecosystem with regard to inorganic nitrogen and estimation of the trophic index.

As a result of the analysis of published data and MHI long-term monitoring of the Sevastopol Bay apex water area, a gradual increase in the salinity of the water area of this part of the Sevastopol Bay was found. This can be due to a variation in the number and intensity of winter-spring floods as a result of the effect of natural and climatic factors.

\section{REFERENCES}

1. Tarasenko, V.S. ed., 2003. [Sustainable Crimea. Water Resources]. Simferopol: Tavrida, 413 p. (in Russian).

2. Myrza, K.L. and Ovcharuk, V.A., 2014. Analysis of the Formation of Cold Period Floods on the Rivers of the Crimean Mountains. Geopolitika i Ekogeodinamika Regionov [Geopolitics and Ecodynamics of Regions], 10(1), pp. 740-745 (in Russian).

3. Ivanov, V.A. and Minkovskaya, R.Ya. 2008. [Sea Mouths of Ukraine Rivers and Estuarial Processes]. Sevastopol: ECOSI-Gidrofizika. Part 1, 448 p. (in Russian).

4. Ovcharuk, V. and Todorova, O., 2016. Determination of Characteristics Maximal Runoff Mountain Rivers in Crimea. Journal of Fundamental and Applied Sciences, 8(2), pp. 525-541. http://dx.doi.org/10.4314/jfas.v8i2.23

5. Repetin, L.N., Gordina, A.D., Pavlova, E.V., Romanov, A.S. and Ovsyany, E.I., 2003. Affect of Oceanographic Factors upon the Ecological State of the Sevastopol Bay (the Black Sea). Morskoy Gidrofizicheskiy Zhurnal, (2), pp. 66-80 (in Russian).

6. Gruzinov, V.M., Dyakov, N.N., Mezenceva, I.V., Malchenko, Yu.A., Zhohova, N.V. and Korshenko, A.N., 2019. Sources of Coastal Water Pollution near Sevastopol. Oceanology, 59(4), pp. 523-532. https://doi.org/10.1134/S0001437019040076

7. Dulov, B.A., Yurovskaya, M.V. and Kozlov, I.E., 2015. Coastal Zone of Sevastopol on High Resolution Satellite Images. Physical Oceanography, (6), pp. 39-54. doi:10.22449/1573160X-2015-6-39-54

8. Boltachev, A.R., Karpova, E.P. and Danilyuk, O.N., 2010. Peculiarities of Thermohaline Parameters and Ichthyocenosis of the Chernaya River Estuary (the Sevastopol Bay). Marine Ecological Journal, 9(2), pp. 23-36 (in Russian).

9. Orekhova, N.A., Medvedev, E.V. and Ovsyany, E.I., 2018. Influence of the River Chernaya Water on Hydrochemical Regime of the Sevastopol Bay (the Black Sea)]. Ecological Safety of Coastal and Shelf Zones of Sea, (3), pp. 84-91. doi:10.22449/2413-5577-2018-3-84-91 (in Russian).

10. Orekhova, N. A., Romanov, A. S. and Khoruzhiy, D. S., 2011. [Interannual Changes of Nutrients Concentration in the Sevastopol Bay in 2006-2010]. In: MHI, 2011. Ecological Safety of Coastal and Shelf Zones and Comprehensive Use of Shelf Resources. Sevastopol: MHI. Iss. 25(1), pp. 192-199 (in Russian). 
11. Kondratiev, S.I., 2014. [Study of the Hydrochemical Structure of the Chernaya River (Crimea) in 2006-2011]. In: MHI, 2011. Ecological Safety of Coastal and Shelf Zones and Comprehensive Use of Shelf Resources. Sevastopol: MHI. Iss. 28, pp. 176-185 (in Russian).

12. Badyukov, D.D., Korneeva, G.A. and Savenko, A.V. 2014. Transformation of Structural and Functional Characteristics of the Mainland Runoff of the River Chernaya and the Sea Waters of the Sevastopol Bay in Winter. Regional Environmental Issues, (3), pp. 7-13 (in Russian).

13. Mukhametov, S.S. and Kondratev, S.I., 2017. Extreme Hydrochemical Parameters in Sevastopol Bay Waters in February 2015 Arising from the Storm Runoff. Vestnik Moskovskogo Universiteta. Seria 5, Geografiya, (6), pp. 9-17 (in Russian).

14. Mikhailova, E.N. and Shapiro, N.B., 2005. Simulation of the Circulation and Space Structure of Thermohaline Fields in the Sevastopol Bay with Regard for the Actual External Data (Winter, 1997). Physical Oceanography, 15(2), pp. 118-132. https://doi.org/10.1007/s11110-005-0035-0

15. Sovga, E.E. and Khmara, T.V., 2019. [Winter Floods on the Chernaya River as a Source of Nutrients into the Sevastopol Bay Apex]. In: MHI, 2019. Seas of Russia: Fundamental and Applied Research: Abstracts of Reports of the All-Russian Scientific Conference. 2328 September 2019. Sevastopol: MHI, pp. 276-278 (in Russian).

16. Ivanov, V.A., Mezentceva, I.V., Sovga, E.E., Slepchuk, K.A. and Khmara, T.V., 2015. Assessment Self-Purification Ability of the Sevastopol Bay Ecosystem in Relation to Inorganic Forms of Nitrogen. Processes in GeoMedia, 2(2), pp. 55-65 (in Russian).

17. Sovga, E.E., Mezentseva, I.V. and Kotelyanets, E.A., 2017. Assimilation Capacity of the Marine Shallow Water Ecosystems with Various Antropogenic Impacts as the Estimation Method of its Self-Purification Ability. Problems of Ecological Monitoring and Ecosystem Modelling, 28(4), pp. 38-51. doi:10.21513/0207-2564-2017-4-38-51 (in Russian).

18. Kotelyanets, E.A., Sovga, E.E. and Mezentseva, I.V., 2017. [Assessment of the Ecological State of the Sevastopol Bay Water Area under the Chernaya River Influence]. In: Sevastopol Branch of MSU, 2017. Proceedings of I International Ecological Forum in Crimea «Crimea is an Ecological and Economic Region. The Space of Noosphere Development». 20-24 June 2017. Sevastopol, pp. 236-240 (in Russian).

19. Mezentseva, I.V. and Sovga, E.E., 2019. Self-Purification Ability of the Ecosystem of the East Part of the Sevastopol Bay with Respect to Inorganic Nitrogen. Ecological Safety of Coastal and Shelf Zones of Sea, (1), pp. 71-77. doi:10.22449/2413-5577-2019-1-71-77 (in Russian).

\section{About the authors:}

Elena E. Sovga, Leading Research Associate, Marine Hydrophysical Institute of RAS, (2 Kapitanskaya Str., Sevastopol, 299011, Russian Federation), Dr. Sci. (Geogr.), ResearcherID: A9774-2018, esovga@mhi-ras.ru

Tat'yana V. Khmara, Junior Research Associate, Marine Hydrophysical Institute of RAS, (2 Kapitanskaya Str., Sevastopol, 299011, Russian Federation), ResearcherID: C-2358-2016, xmara@mhi-ras.ru

Contribution of the co-authors:

Elena E. Sovga - scientific supervision of the research, setting out the objectives and tasks of the research; the processing and description of the results of the study, participation in the discussion of the article materials, formulation of the conclusions, preparation of annotation text, critical analysis and revision of the text, preparation of the article text

Tat'yana V. Khmara - analysis of the materials on the research theme, literature review in the research problem, construction of graphs and diagrams, selection and analysis of the literature, participation in the discussion of the article

All the authors have read and approved the final manuscript.

The authors declare that they have no conflict of interest. 